\title{
THE MARIKANA MASSACRE, LABOUR AND CAPITALISM: TOWARDS A RICOEURIAN ALTERNATIVE
}

\begin{abstract}
Author:
J. F. Boëttger ${ }^{1}$

M. Rathbone ${ }^{2}$

\section{Affiliation:}

${ }^{1}$ Director Human Resources

Empowerment Group (Pty) Ltd

${ }^{2}$ Faculty of Economic and Management Sciences, NorthWest University, Potchefstroom Campus
\end{abstract}

\section{Correspondence to: \\ Jaco Boëttger}

\section{Postal Address:}

327 Malherbestraat, Capital

Park, Pretoria, 0084

\section{Email:}

jaco.boettger@hre-consulting. co.za

\section{Correspondence to:}

Mark Rathbone

\section{Postal Address:}

Private Bag X6001,

Potchefstroom Campus, NorthWest University, Potchefstroom, 2520, South Africa

Email:

mark.rathbone@nwu.ac.za

Dates:

15 Des 2016

\section{How to cite this article:}

Boëttger, J. F. \& Rathbone, M., 2016. "The Marikana Massacre, labour and capitalism: Towards a Ricoeurian alternative". KOERS - Bulletin for Christian Scholarship, 81(3). Available at: https://doi.org/10.19108/ KOERS.81.3.2263

\section{Copyright:}

(c) 2016. The Author(s). Published under the Creative Commons Atribution License.
The purpose of this article is to critically discuss the tragedy that occurred between 11 and 16 August 2012 at the Lonmin Mine in Marikana, South Africa. Although the events leading up to the Marikana massacre were complex and not one single factor was responsible for the tragedy we will focus on the philosophical and anthropological aspect that may have influenced the breakdown of engagement between the management of Lonmin and workers. It will be argued that this breakdown may have been the result of reductionist anthropological trends that arise in capitalism. These trends selectively utilize modern economic principles to advance the profit motive of business and dehumanises workers. This dehumanisation is clear in the view of workers by the Lonmin management and breakdown of communication. In order to provide an alternative anthropology the philosophy of Paul Ricoeur with special reference to his work Fallible man (1986) is explored and applied as an alternative anthropology for the reductionist trends related to labour that sporadically arise in capitalism. This offers a balanced view that incorporates the aim of responsible business to make profit with that of a sustainable labour market.

KEYWORDS: Marikana massacre, capitalism, anthropology, Paul Ricoeur

Die doel van hierdie artikel is om 'n kritiese bespreking te doen van die tragedie wat tussen 11 en 16 Augustus 2012 afgespeel het by die Lonmin-myn in Marikana, Suid-Afrika. Hoewel die gebeure wat aanleiding gegee het tot die Marikana-slagting kompleks is en nie gereduseer kan word tot een enkele faktor wat verantwoordelik was vir die tragedie nie, sal ons fokus op die filosofiese en antropologiese aspekte wat gelei het tot die ineenstorting van die kommunikasie tussen die bestuur van Lonmin en die werkers. Daar sal aangevoer word dat hierdie ineenstorting die gevolg kon wees van reduksionistiese antropologiese neigings wat binne die raamwerk van kapitalisme ontwikkel. Hierdie neigings maak op ' $n$ selektiewe basis gebruik van modern ekonomiese beginsels om die winsmotief van besighede te bevorder, en dit lei tot die ontmensliking van die werker. Hierdie ontmensliking is duidelik sigbaar uit die oogpunt van die werkers teenoor die agtergrond van die Lonmin-bestuur en die ineenstorting van kommunikasie tussen die partye. Om ' $n$ alternatiewe antropologie voor te stel, word ondersoek ingestel na die filosofie van Paul Ricoeur, met spesifieke verwysing na sy werk Fallible man (1986) en dit word toegepas as 'n alternatiewe antropologie vir die reduksionistiese neigings wat saamhang met arbeid soos wat dit sporadies in kapitalisme opduik. Dit bied ' $\mathrm{n}$ gebalanseerde gesigspunt wat die doel van verantwoordelike besighedspraktyke (om wins te maak) inkorporeer met ' $n$ volhoubare arbeidsmark.

\section{SLEUTELWOORDE: Marikana-slagting, kapitalisme, antropologie, Paul Ricoeur}




\section{INTRODUCTION}

The Marikana massacre refers to the events of 11 to 16 August 2012 at the Lonmin Mine at Marikana where 44 people lost their lives, more than 70 were injured, approximately 250 people were arrested and millions of rands of property damaged. These events were preceded by a wage dispute between worker unions and the Lonmin management. The events were exacerbated by a dispute between the National Union of Mineworkers (NUM) and the newly-formed Association of Mineworkers and Construction Union (AMCU). The eventual tragedy also involved the South African Police Service (SAPS) that used the most lethal force against civilians since the Sharpeville massacre of 1960 (Chinguno, 2013:1).

There are many similarities between the Sharpeville and Marikana massacres. The SAPS without warning fired into an unarmed crowd at Sharpeville in Vereeniging, killing at least 69 anti-pass law protesters. This incident was seen by many scholars as a turning point in the struggle against apartheid. Although this incident happened more than 50 years ago it united the oppressed masses against the National Party Government, in much the same way as the Marikana massacre. The Marikana tragedy also united the masses; however, unlike Sharpeville that focused on apartheid laws, Marikana was a protest against economic inequality and injustice. Therefore, the protests by the employees of Lonmin at Marikana had a clear economic agenda that can be traced back to economic exploitation of the colonial and apartheid eras in South Africa. One of the primary demands of the workers was a wage of R12 500 per month. Lonmin management considered the R12 500 increase to be completely unrealistic and the miners responded by engaging in protest and strike action. This demand is about ten times less than the wage of miners in Australia and the United Kingdom (Alexander, 2013:26). It is clear that the colonial and apartheid legacy that justified economic inequality based on race had not been addressed since the first democratic election of 1994.

The tragedy that happened at Marikana is an important warning that economic inequality in South Africa (the second highest in the world after Lesotho) can have devastating consequences to the stability of the country and democracy. Piketty (2014:1) highlights the phenomenon of inequality as being at the core of the problems facing global capitalism. He states the following regarding the events that took place at Marikana (2014:39):

This episode reminds us, if we need reminding, that the question of what share of output should go to wages and what share to profits - in other words, how should the income from production be divided between labour and capital? - has always been at the heart of distributional conflict.

The events leading up to the Marikana massacre are complex and not one single factor was responsible for the tragedy. In this article the focus is on the philosophical and anthropological aspects that may have influenced the breakdown of engagement between the management of Lonmin and workers. It will be argued that this breakdown of communication may have been the result of reductionist anthropological trends that arise in capitalism. These trends selectively utilize modern economic aspects (of people like Adam Smith and Karl Marx) like selfinterest and laissez-faire economics and labour to advance the profit motive of business (Rathbone 2012:20). It can therefore happen that workers are dehumanised and reduced to production factors with a particular monetary value that must be kept as low as possible to ensure maximum profit. This dehumanisation is clear in the breakdown of communication between Lonmin and worker.

Although Smith, from a popular perspective, is undoubtedly seen as the father of reductionist modern economic philosophy, it might be an over-simplification of his work. Smith did state that self-love was at the core of all economic interactions and supported the much written about invisible hand concept of market forces but nevertheless, according to Rathbone (2015:19), clearly stated that sympathy guides how self-love functions in society with the possibility of benevolence. Rathbone (2015:20) points out that Smith even conceded that interventions might be needed under certain circumstances. Sen (2010:52) also explains that Smith pointed out that markets need restraints and correction through other institutions to prevent inequity and poverty. It seems that the self-love theory and the invisible hand of Smith have been used to champion the causes of many writers without their understanding the complexity and moral basis of much of his writings. As Sen (2010:54) puts it: "This is indeed the standard view of Smith that has been powerfully promoted by many writers who constantly invoke Smith to support their view of society." Despite Sen and Rathbone's warning it seems that the popular view is to associate Smith's economic philosophy with greed and excess to promote some reductionist capitalist trends.

In order to provide an alternative anthropology the philosophy of Paul Ricoeur with special reference to his work Fallible man (1986) is explored and applied as an alternative anthropology for the reductionist trends related to labour that sporadically arises in capitalism. Danhauer and Pellauer (2014:1) note that Ricoeur's anthropology is that of the "capable human being" that refers to the complexity of being human that encompasses capabilities and vulnerabilities.

Ricoeur does not deny humankind's propensity for evil and goodness, to be capable or incapable. He therefore does not reduce humans to one or the other, but suggests that we can choose how we act. In this article it will be argued that Ricoeur's philosophical anthropology of viewing humankind as fundamentally fallible but also as responsible agents with choice and vast possibilities, offers better solutions to the dilemma of inequality perpetuated by certain reductionist trends of capitalism.

In the first section of this article the possibility of reductionist trends of capitalism that selectively utilise modern economic philosophy will be explored. Next, the link between the violent incident at Marikana and reductionist anthropological views embedded in capitalism, with specific reference to labour, will be discussed. This will be followed by a proposal that Ricoeur's philosophical anthropology may provide a more humane 
alternative that recognises the complexity of being human. Finally, the possible implications of Ricoeur's anthropology for business will be discussed.

\section{CAPITALISM AND THE GENERAL REDUCTIONIST VIEW OF LABOUR}

The general definition of labour or "human effort" in economic textbooks like that of Mohr (2010) is as follows:

Labour may be defined as the exercise of human mental and physical effort in the production of goods and services. It includes all human effort exerted with a view to obtaining reward in the form of income (Mohr 2010:8).

What is clear from this definition is that labour is regarded as a factor of production of goods and services, amongst others like natural resources, capital and entrepreneurship that is used in the effort of business to make money (Mohr, 2010:8). In this regard, the labourer sells his or her labour in order to derive an income. The price of labour is crucial to the profit made by business and has therefore to be kept as low as possible. The labour market is therefore one of the crucial functions of the prosperity of business. In other words, the definition of labour in a capitalist system has a reductionist anthropology that reduces human-beings to functions of production in the effort to make profit. Human beings are viewed as aspects of an economic system (or homo economicus in some instances). The problem is that the labour market does not only function as a consequence of supply and demand with the possibility of reaching equilibrium through the invisible hand or the providence of God (Goudzwaard, 1979:22). Rather, the market, specifically in South Africa with a legacy of inequality related to colonialism and apartheid, is geared in such a way as to always produce an over-supply of labour. This situation is certainly not what Adam Smith had in mind in his economic philosophy (Rathbone, 2016). Self-interest and market equilibrium were never envisioned in a situation of injustice. According to Smith (2013) the economy cannot function properly without justice as a core motive. It seems that Sen (2010) is correct that this view of Smith is a means to justify crude capitalism that fails to recognise the importance of equal opportunity as an important pillar of capitalism and neo-liberalism.

The general reductionist capitalist view of human beings understands labour as factors of production and all human effort as inherently calculable, rational and self-interested. The implication for labour, in a context like South Africa with grave economic inequalities, unemployment and legacy issues related to apartheid and colonialism, is that the labour market becomes dysfunctional. If all people are viewed as homo economicus the implication is that the rational, self-interested labourer will not work for a wage that does not reflect his or her effort and/or needs for a humane standard of living. However, unemployment and inequality impede the choices of labourers. If there are no other employment opportunities it can easily happen that labour is (often grossly) exploited.
It is important to remember that capitalism borrowed from modern economic philosophy in order to support the agenda of business by selectively focusing on aspects of Smith and even Marx that support their agenda. Rathbone (2012:19) notes that the influence of modern philosophers like Locke, Hobbes and Hume contributed to the development of modern economics, with Marx as foil. However, the nuanced view of self-interest and of humanity of Smith in his discussion of sympathy and justice never received the attention it requires. Exploitative trends in capitalism simply selectively borrowed from modern economic and reduces the person to a cog in a super-rational money-driven machine in order to make profit.

With this statement an intentional reduction of people to the role of slaves serving the monster machine they have created is not suggested, but rather an accidental outcome of an envisioned modernistic and perfectly rational humanistdriven utopia gone wrong. This linear and rational view of labour by capitalists can simply not accommodate the real complexity of the organic, systemic and dynamic nature of human-beings at work in the global village.

In endeavouring to understand the anthropological view of capitalism on an even deeper level, one should take note of Tarnas' (1991:388) observation:

The great overriding impulse defining Western man since the Renaissance - the quest for independence, self-determination and individualism - had indeed brought those ideas to reality in many lives; yet it had alsoeventuatedinaworld whereindividual spontaneity and freedom were increasingly smothered, not just in theory by a reductionist scientism, but in practice by the ubiquitous collectively and conformism of mass societies. The great revolutionary political projects of the modern era, heralding personal and social liberation, had gradually led to conditions in which the modern individual's fate was ever more dominated by bureaucratic commercial and political superstructures. Just as man had become a meaningless speck in the modern universe, so had individual persons become insignificant ciphers in modern states, to be manipulated or coerced by the millions.

The collusion of liberalism and capitalism that was supposed to enable man to conquer nature for the ultimate good of the human race leaves workers as victims of atomism. In other words, this ontology implies that people are disconnected and disinterested individuals who function autonomously and for personal gain. Tarnas (1991:357) also describes this dilemma, induced by the impact of the quantum-relativistic revolution, when he writes:

The deep interconnectedness of phenomena encouraged a new holistic thinking about the world, with many social, moral, and religious implications. Increasing numbers of scientists began to question modern science's pervasive, if often unconscious, assumption that the intellectual effort to reduce 
all reality to the smallest measurable components of the physical world would eventually reveal that which was most fundamental in the universe. The reductionist program, dominant since Descartes, now appeared too many to be myopically selective, and likely to miss that which was most significant in the nature of things.

It isolated and de-humanised the individual to make possible the deployment of this so-called human resource or factor of production and only one more part of a capitalist wealthcreating machine. This very reductionist tendency, we will explain later, is one of the core factors that probably had an impact on events that led to the Marikana incident. This reduction of labour as a mere production factor was not only linked to capitalism's selective use of modern economic philosophy. Capitalism also selectively borrowed from Calvinism. The impact of the Calvinistic idea that the creation of wealth is commanded by God can also not be underestimated. Tarnas (1991:245) explains that "a Christian's worldly vocation was to be pursued with spiritual and moral fervor in order to realize the Kingdom of God on earth". Therefore, this Calvinistic individualism gave the embryonic modern psyche religious sanction that influenced all spheres of life. Tarnas (1991:246) thus partly lays the failure of the current system at the door of the Reformation when he observes that "the striving Christian, deprived of the Catholic's recourse to sacramental justification, could find signs of his being among the elect if he could successfully and unceasingly apply himself to disciplined work and his worldly calling".

It can therefore be argued that capitalism globally and also to a large extent in the South African context was probably also justified and driven by an underlying and even sub-conscious religious zealousness. This can specifically be seen in South Africa and other developing nations in the way mining houses like Lonmin function with dual listings (Goudzwaard \& De Santa Ana, 2005:8). In the case of Lonmin it is listed on the Johannesburg Stock Exchange and the London Stock Exchange $^{1}$.

In the next section the spotlight shifts to the consequences of capitalism's view of labour as was seen in the events that preceded the Marikana tragedy.

\section{MARIKANA, CAPITALISM AND LABOUR}

The results of interviews with workers who survived the attack at Marikana are compiled in the work of Alexander et al., Marikana: Voices from South Africa's mining massacre (2013). In this publication the voices of workers become the revealing testimony of the dehumanisation and reduction of labour at the Lonmin mine at the mercy of capitalism. It is mentioned numerous times in the book that one of the salient aspects in the events that preceded the massacre was the way in which the

Alexander (2013) reminds us that as far back as 1973, Lonmin, then called Lonrho, was described by Edward Heath, the Conservative Prime Minister, as an unacceptable face of capitalism, a portrayal Alexander thinks many will still find apt today. management of Lonmin related to labour. This relationship was marked by a failure to listen to and respect the humanity of workers, according to Alexander et al. (2013). A mineworker referring to housing noted that they were closed in with wire like they were cows. One of the miners' wives said she felt that fencing was for rats and dogs. A miner sadly recounted how he explained to the employer that they (the miners) were also human. This lack of respect for the workers was echoed by the Marikana Commission of Inquiry (2015:542): “The commission is satisfied that Lonmin's failure to comply with its housing obligations created an environment conducive to the creation of tension, labour unrest, disunity among its employees or other harmful conduct." Lonmin argued that providing 5500 houses to its workers would not have stopped the Marikana incident from happening ... to which, according to the Marikana Commission of Inquiry (2015:540), Mr Chaskalson SC replied:

... quite a breathtaking argument for Lonmin to make. It amounts to an argument that Lonmin has been so neglectful of the housing needs of its workforce that the 5500 houses in their SLP would have been no more than a drop in the ocean of squalor in which they expect their workers to live.

With the above-mentioned in mind, it is very easy to see why the disenfranchised and marginalised masses in the world and in South Africa can feel frustrated, angry and dehumanised. It seems that Lonmin did not give adequate attention to the needs of the workforce regarding housing. Another omission was management's inability to deal with the complex ethnic demographic of the workers. The resistance of the workers was a means to affirm their collective and individual humanity by demanding an adequate wage (Alexander, 2013).

The reduction of labour and dehumanisation is also a clear attempt to address the legacy of apartheid that specifically plagues the mining industry and exacerbates economic inequality and poverty. The Truth and Reconciliation Commission $^{2}$ of nearly a decade before the massacre highlighted that economic injustice is one of the core legacies of apartheid that requires urgent rectification (Rathbone, 2016). It seems that the inability to deal with these crucial human rights issues is one of the many contributing factors to the loss of life and chaos that ensued.

\section{PAUL RICOEUR AND A MORE ENCOMPASSING ANTHROPOLOGY}

In this section the philosophy of Paul Ricoeur with special reference to his work Fallible man (1986) is explored as a possible alternative to the general reductionist anthropology embedded in capitalism. Ricoeur's work is explored because it will be argued that he provides a more encompassing anthropology that is critical of human evil and injustice. His anthropology

\footnotetext{
2 The Truth and Reconciliation Commission was chaired by Archbishop Emeritus Desmond Tutu and served as a platform for South Africans to achieve reconciliation by revealing abuses under apartheid and to apply for amnesty for these acts.
} 
also highlights the capacity of people to be responsible and act in a manner that is respectful towards others.

Ricoeur believes that human-beings are indeed fallible. In other words, people can be, in agreement with the Kantian perspective, radically evil, misuse their freedom and have a bad will. Ricoeur sees our potential to be evil as grounded in a basic disproportion that characterises the finite and infinite dimensions of a human-being. According to Dauenhauer and Pellauer (2014:3), "[t]his disproportion is epitomised by the gap between bios, or one's spatio-temporally located life, and the logos, one's use of reason that can grasp universals". However, the possibility exists that people may also reach out beyond turmoil and disaster. This happens when reconciliation and mutual respect become an act of will within the dialectic of time.

Ricoeur (1978:30) notes that a dialectic tension between the finite and infinite, the polarity that causes the fragility of the human being, can and should be addressed in the synthesis of understanding and sensibility, of character and happiness. He refers to and supports Kant's position that the person is then a task rather than a reality. This task, according to Ricoeur (1978:30-31), is a reconciliation of the longing for infinite happiness and the finite reflections of our own character. This reconciliation or mediation takes place through respect. Respect is for Ricoeur the ability to see the other in the self. Respect does not cancel out the dialectic tension between happiness and character, between infinity and the finite, but rather presupposes it. Ricoeur (1978:25) emphasises humankind's ability to achieve an intentional synthesis of finite and infinite, meaning and presence.

Ricoeur (1978:30) notes that this act of respect in the dialectic of time is the space where happiness and the formation of character become a reality. Ricoeur (1978:30) states that we do not see the person as a function of "imminent right"; rather, as the identification of the self through the other. In other words, respect starts with self-respect - "I ought to respect the person 'in' the other and 'in' myself" (Ricoeur 1978:30). Therefore, respect "... reconciles the finitude of desire and the infinitude of reason and happiness only by making possible the very idea of man which serves as the ideal mediator between practical reason and sensibility". For Ricoeur (1978:31), respect becomes the fragile bond between morality (the recognition of the other longing for happiness), and sensibility (my own narrow and limited perspective and character).

This more encompassing anthropology is linked to a new view of self, existence and life. Ricoeur (1986:1-37) states that existential loneliness "through its pole of infinitude, assures me that I can 'continue my existence in' the openness of thinking and acting; the originating affirmation is felt here as the joy of 'existing in' the very thing that allows me to think and to act; then the reason is no longer another: I am it, you are it, because we are what is". In other word, a more egalitarian existential anthropology informed by respectful engagement is at the core of Ricoeur's philosophy.

For Ricoeur (1986:138) human-beings are the "plural and collective unity in which the unity of destination and the difference of destinies are to be understood through each other". Dauenhauer and Pellauer (2014:3) describe Ricoeur's philosophical anthropology as a quest for genuine mutuality and esteem for the worth we have as unique beings ${ }^{3}$. In his

final book, The course of recognition (2004), Ricoeur specifically points out that this recognition must go beyond the mere reciprocal recognition found in commercial transactions ${ }^{4}$.

The Ricoeurian anthropology fundamentally represents a more respectful view of what humans are and what we can accomplish. It is invitational and prepares the way for inclusive, caring and action-based relationships. This anthropology also challenges the reciprocity of the economic cycle and envisions a more sustainable society. It also closes the door on making the modern economic philosophy the scapegoat for the reductionist trends in capitalism. However, the alternative is highlighted in which people take personal and collective responsibility economic actions.

\section{THE IMPLICATIONS OF RICOEUR'S ANTHROPOLOGY FOR BUSINESS}

Crispen Chinguno (2013:1) of the Global Labour Column notes that the Marikana massacre can be directly linked to the failure of institutional structures of collective bargaining. Alexander (2013:152) highlights that this breakdown was mainly due to the refusal of Lonmin's management to engage with workers constructively. A possible reason for this refusal to engage may be found in the reductionist view embedded in capitalism. Workers are only production factors and when demands are made that affect the profits of a company they are simply dismissed as irrational and irresponsible. We suggest in this article that a more humane approach infused by Ricoeur's more encompassing anthropology may have had a different result. This does not mean that business aims like profitability are not important. Respect for people does not exclude responsible business practice. On the contrary, when people are engaged and treated with dignity, fear and aggression are overcome by renewed awareness and understanding of the aim of business to be healthy and profitable. Profitability does not only benefit shareholders. It is crucial for the creation of employment and sustaining the labour market. However, this perspective is more than a business transaction with mutual benefits. It goes further and includes the way people relate to one another on an interpersonal level as human-beings.

Ricoeur (1987:30) specifically pointed out that we should go beyond the mere reciprocal recognition found in commercial transactions (Dauenhauer \& Pellauer, 2014). In praxis, this means that a more encompassing style of stakeholder engagement is developed that is rooted in mutual respect. Corporate social responsibility then becomes an extension and function of a deeply-held conviction of what makes us

3 Unlike Ricoeur, Smith was skeptical and suspicious of a philosophical vantage point that would interfere in man's natural sound judgement (see Fleischacker, 2013:1).

4 Compared to Ricoeur's "plural view of man", Smith's reductionism really becomes abundantly clear (see Dauenhauer \& Pellauer, 2014:3). 
human. And this, in Ricoeur's (1987:30) own words, "serves as the ideal mediator between practical reason and sensibility". For Ricoeur (1978), respect is the glue that keeps morality and sensibility together.

Hamel (2009:91) notes that this means that respect must be translated in the "language and practice of business". Hamel also specifically encourages businesses to develop an egalitarian business ethos and citizenship that recognises the interdependence of all stakeholders. Freeman et al. (2004:364) note that respect is one of the core values of stakeholder theory. This has the economic benefit that "... value is created by people who voluntarily come together and cooperate to improve everyone's circumstance" (Freeman, 2004:364).

It is clear that the reciprocal nature of Ricoeur's anthropology has implications for business practice and capitalism. This is highlighted by Waddock (2014:2) who notes that the challenges facing business and capitalism require a new way of thinking in which reciprocal recognition is paramount in addressing problems like unemployment, poverty and economic inequality ${ }^{5}$. She refers to this new way of thinking as postconventional reasoning that “... involves an ability to think systemically, in paradigms and across systems, really being able to understand that there are multiple ways of viewing things, none of which has all the answers or is fully 'right'. It involves having the ability to put oneself in the position of the other" (Waddock, 2014:2).

The implication of the recognition of the other is that we are challenged to extend beyond our own comfort zone and enter the unknown. Kearny (2011:5) notes that this means that "I transcend the familiar limits of subjective consciousness and open myself to possible new worlds". This moment of transcendence into unknown is something that is rather avoided by business because of the risk that the unknown represents. However, it is also the risk related to the unknown that has led to innovation and the ability of business to take a leading role in addressing the challenges facing the world.

\section{CONCLUSION}

In this article the Marikana massacre was related to reductionist anthropological trends associated with capitalism that may have influenced the way the management of Lonmin addressed wage negotiations with the labour force. In this regard, the Lonmin management consciously or inadvertently operated from a view of labour promoted by capitalism that reduces labour to factors of production. This is clearly disrespectful of the humanity of workers because labourers are mainly seen as means to increase profit by reducing wage costs. This does

\footnotetext{
According to Muller and Roberts (2015), the businessman Johann Rupert commented on our current economic thinking at the Financial Times Business of Luxury summit in Monaco in June 2015 by saying: "We cannot have $0,1 \%$ of $0,1 \%$ taking all the spoils. It is unfair and not sustainable." Rupert added: "How is society going to cope with structural unemployment and the envy, hatred and the social warfare? We are destroying the middle classes at this stage and it will affect us. It's unfair. So that's what keeps me awake at night".
}

not take into consideration the needs of labourers to create a sustainable living. This reduction of labour is often associated with modern economic philosophy. However, it was shown that trends in capitalism that reduce labour usually selectively borrow from the philosophies of people like Smith and Marx to promote their agendas to make profit.

The philosophical anthropology of Ricoeur was proposed as an alternative. His philosophy advocates a more encompassing view of human beings that is centred on respect for others and the reciprocal recognition of the other that challenges the status quo. This challenge is helpful because it is a critique of reductionist trends in capitalism and can assist to start addressing contemporary problems like poverty, unemployment and economic inequality. This offers a balanced view that incorporates the (legitimate) aim of responsible business to make profit with that of a sustainable (and ethically justifiable) labour market.

\section{DECLARATION OF CONFLICTING INTERESTS}

The author(s) declared no potential conflicts of interest with respect to the research, authorship, and/or publication of this article.

\section{FUNDING}

The author(s) received no financial support for the research, authorship, and/or publication of this article. 


\section{BIBLIOGRAPHY}

Alexander, P., Lekgowa, T., Mmope, B., Sinwell, L. \& Xezwi, B. 2013. Marikana: Voices from South Africa's mining massacre. Athens: Ohio University Press.

Chinguno, C. 2013. Unpacking the Marikana massacre, Global labour column. Available at http://column.global-labour-university.org/2013/02unpacking-marikanamasacre.html [Accessed: 5 May 2013].

Dauenhauer, B. \& Pellauer, D. 2011. Paul Ricoeur. The Stanford Encyclopaedia of Philosophy. Available at http://plato.stanford.edu/archives/sum2014/entries/ ricoeur/ [Accessed: 28 May 2015].

Fleischacker, S. 2013. Adam Smith's moral and political philosophy, The Stanford Encyclopaedia of Philosophy. Available at http://plato.stanford.edu/archives/ spr2013/ entries/smith-moral-political [Accessed:28 May 2015].

Freeman, R., Wicks, A. \& Parmar, B. 2004. Stakeholder Theory and The Corporate Objective Revisited. Organization Sciences, 15(3):364-369.

Goudzwaard, B. 1979. Capitalism and progress. Grand Rapids: Eerdmans.

Goudzwaard, B. \& De Santa Ana, J. 2005. Globalisation and the spirit of modernity, Beyond idealism, De Santa Ana J (ed). Grand Rapids: Eerdmans.

Hamel, G. 2009. Moon shots for management Harvard Business Review, 87(2):91-98.

Kearny, R. 2011. On Paul Ricoeur: The owl of Minerva. Burlington: Ashgate.

Marikana Commission of Inquiry, 2015, Report on matters of public, national and international concern arising out of the tragic incidents at the Lonmin Mine in Marikana, in the North West Province. Available at http://www.gov.za/sites/www. gov.za/files/marikana-report-1.pdf [Accessed: 3 August 2015].

Mohr, P. 2010. Understanding the economy. Pretoria: Van Schaik Publishers.

Muller, T. \& Roberts, A. 2015. A billionaire Rupert sees wealth gap fuelling social unrest. Available at http://www.moneyweb.co.za/category/news/economy [Accessed: 11 June 2015]

Piketty, T. 2014. Capital in the twenty-first century. Harvard, London: Belknapp.

Rathbone, M. 2012. Unemployment and "the gift" in the South African context. Mini-Dissertation submitted in partial fulfilment of the requirements of the degree Magister Philosophiae at the Potchefstroom Campus of the North-West University.

Rathbone, M. 2015. Love, money and madness: money in the economic philosophies of Adam Smith and Jean-Jacques Rousseau. South African Journal of Philosophy, 34:3, 379-389.

Rathbone, M. 2016. Reframing the Tower of Babel narrative for economic justice within the South African context, HTS Teologiese Studies/Theological Studies 72(3), a3490. http://dx.doi. org/10.4102/hts.v72i3.a3490

Ricoeur, P. 1978. The philosophy of Paul Ricoeur: An anthology of his work. In Reagan, C. E. \& Stewart, D. (eds.). Boston: Beacon Press.

Ricoeur, P. 1986, Fallible man. New York: Fordham University Press.

Ricoeur, P. 2004. The course of recognition. Translated by D., Pellauer. London: Harvard University Press.

Sen, A. 2010. Adam Smith and the contemporary world Erasmus Journal for Philosophy and Economics. 3(1), 50-67, Available at http://ejpe.org/pdf/3-1-art-3. pdf

Smith, A. 2013. The invisible hand of the market: The theory of moral sentiments \& the wealth of nations [Kindle ed.] Available at http://www.amazon.com.
Tarnas, R. 1991. The passion of the Western mind, understanding the ideas that have shaped our world view. New York: Ballantine Books.

Waddock, S. 2014. Wicked problems, Reflect 3: The Albert Luthuli Centre for Responsible Leadership, University of Pretoria, Pretoria. 